\title{
Biological Nitrogen Removal in a Flow-Separating Biochemical Reactor with Coral Sand
}

\author{
Xiangyu Long1, Ran Tang1,2*, Bo Zhan', Zhendong Fang1, \\ Chaoxin Xie', Yongqin Li ${ }^{1}$ \\ ${ }^{1}$ Department of Military Installations, Army Logistics University of the People's Liberation Army, \\ University Town, Chongqing, China \\ ${ }^{2}$ College of Chemistry and Chemical Engineering, Chongqing University of Science and Technology, \\ Chongqing, China
}

Received: 28 July 2018

Accepted: 27 October 2018

\begin{abstract}
In order to provide some support for economically and effectively resolving the problem of water pollution around the islands in the South China Sea, biological nitrogen removal (BNR) performance and biotechnological characterization of the FSBR filled with abandoned coral sand were investigated. The results showed that the TN removal efficiency of the FSBR with a good performance of simultaneous nitrification and denitrification (SND) was $74.68 \pm 6.49 \%$ during the stable operation. The total biomass and removal efficiency of pollutants in the three reaction regions all decreased along the flow direction. Therefore, the first region was the key area for SND reaction and TN removal. In the first region, the nitrification process was the result of the combination of autotrophic nitrification and heterotrophic nitrification. Meanwhile, aerobic denitrification played a key role in the process of denitrification. In the region, the most denitrifying bacteria belonged to Proteobacteria, in which unclassified_f_Comamonadace, Acidovorax and Dokdonella were the major aerobic denitrifying bacteria.
\end{abstract}

Keywords: aerobic denitrification; biological nitrogen removal (BNR); coral sand; flow-separating biochemical reactor; simultaneous nitrification and denitrification (SND)

\section{Introduction}

With the development and construction of islands in the South China Sea, the problem of marine pollution from the discharge of domestic sewage becomes serious. The treatment of domestic sewage is an

*e-mail: tangranhncq@126.com important strategy to control the water environmental quality around the islands. Nitrogen is a key factor of waterbody eutrophication and an important object of domestic sewage treatment $[1,2]$. At present, biological nitrogen removal (BNR) is an economical and effective way to remove nitrogen in domestic sewage [2]. In recent years, Simultaneous nitrification and denitrification (SND) has received wide attention [3-5]. Compared with the conventional anoxic/oxic (A/O) denitrification technology, SND has many 
advantages: (1) Saving occupation space and capital investment cost, (2) Reducing operating cost and energy consumption, and (3) Improving operational stability. Therefore, it is of great significance to offer an appropriate SND technology of domestic sewage treatment for the islands in the South China Sea.

Flow-separation biochemical reactor (FSBR) integrating the principles of biological contact oxidation and flow separation is an efficient wastewater treatment technology [6]. The technology has the characteristics of high efficiency and simple operation, without a secondary settling tank, mixed liquid recycle, sludge return and waste sludge discharge [7]. Therefore, the FSBR should be an appropriate technology for domestic sewage treatment of the islands. However, there were few reports on the SND performance of the FSBR.

In the process of SND, there were not only autotrophic nitrification and anoxic denitrification, but also heterotrophic nitrification and aerobic denitrification $[8,9]$. Thereby, the BNR performance of FSBR should be closely related to microbial population. Furthermore, the microbial population of FSBR should be affected by different forms of microbial aggregate (including suspended solid, loosely attached biofilm and tightly attached biofilm) and pollutant concentrations (decreasing along the flow direction). In order to understand the performance and characteristics of BNR in the FSBR, it is necessary to investigate the microbial community characteristics in the different forms of microbial aggregate along the flow direction.

Coral sand is widespread in islands of the South China Sea, which has a rough surface and porous structure [10]. Therefore, coral sand should be suitable as a biofilm carrier. If utilizing abandoned coral sand as the filler of flow-separated ball, the construction cost of a sewage treatment system in the South China Sea could be reduced substantially. In the study, abandoned coral sand was used as the filler of flow-separated ball in FSBR. In order to provide some support for economically and effectively resolving the problem of water pollution around the islands in the South China Sea, the BNR performance and biotechnological characterization of the FSBR were investigated. Firstly, nitrogen removal efficiency of the FSBR filled with abandoned coral sand was studied during the start-up and steady operation, after analyzing physicochemical properties of coral sand. Secondly, the changes of pollutant removal efficiency and microbial biomass along with the flow direction in the FSBR were analyzed to understand BNR performance. Finally, the microbial community characteristics of the different forms of microbial aggregate along the flow direction were investigated, and then the biotechnological characterization of BNR in the FSBR were discussed.

\section{Material and Methods}

\section{Experimental Installation and Inflow Quality}

A pilot-scale FSBR was used to treat domestic sewage in the West Campus of the Army Logistics University of PLA, China. The FSBR included a water-distribution area, a reaction area and an exhalant area (Fig. 1). The working volume of the reaction area was $0.576 \mathrm{~m}^{3}$. In addition, the reaction area was divided into three reaction regions by perforated plates, of which the perforated rate was $12.56 \%$. In order to study pollutant removal efficiency along the flow direction, six sampling points were set at equal distance in the reaction area, where flow-separated balls made of polypropylene with a diameter of $10 \mathrm{~cm}$

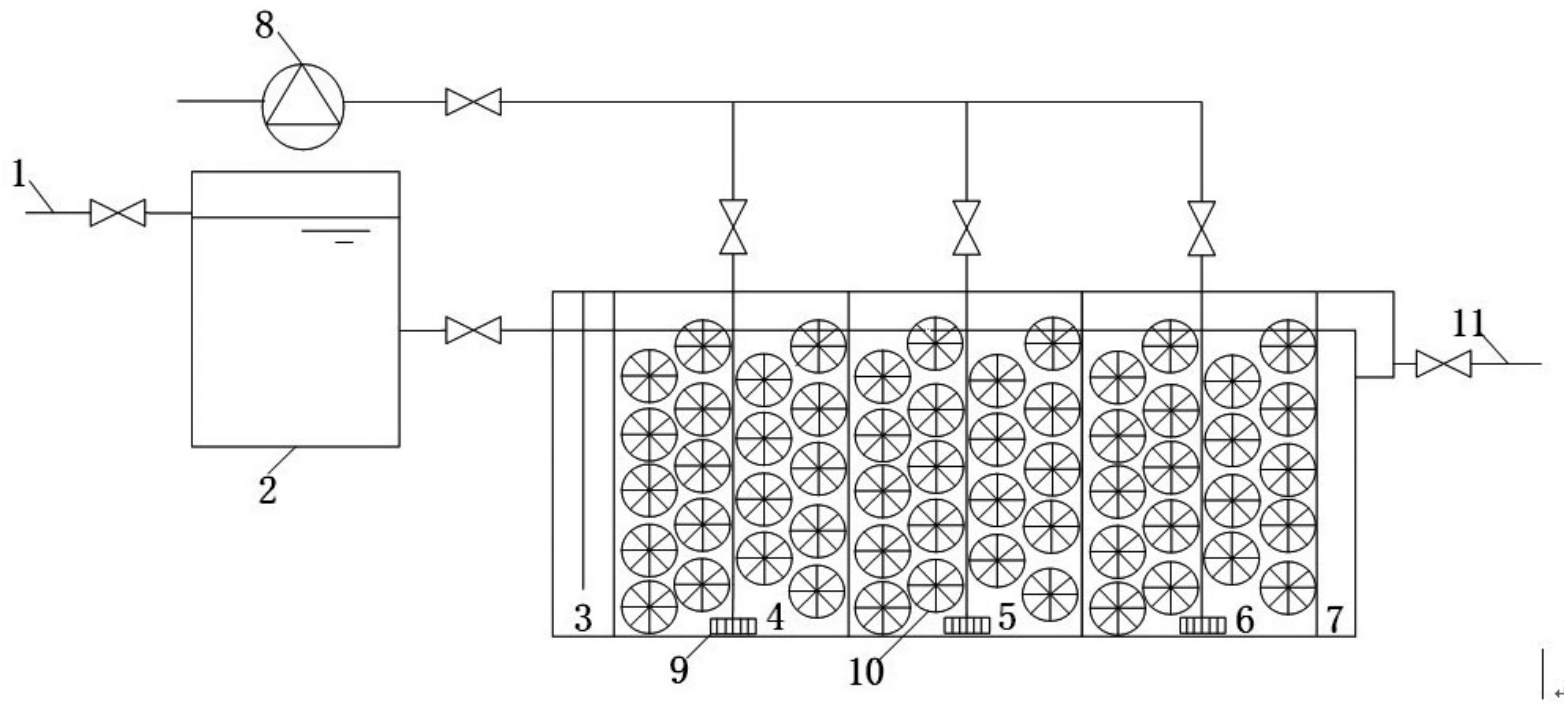

Fig. 1. Schematic diagram of flow-separating biochemical reactor: 1) Influx, 2) Head tank, 3) Water distribution area, 4) First reaction region, 5) Second reaction region, 6) Third reaction region, 7) Exhalant area, 8) Air pump, 9) Aerator, 10) Flow-separating ball, 11) Efflux. 

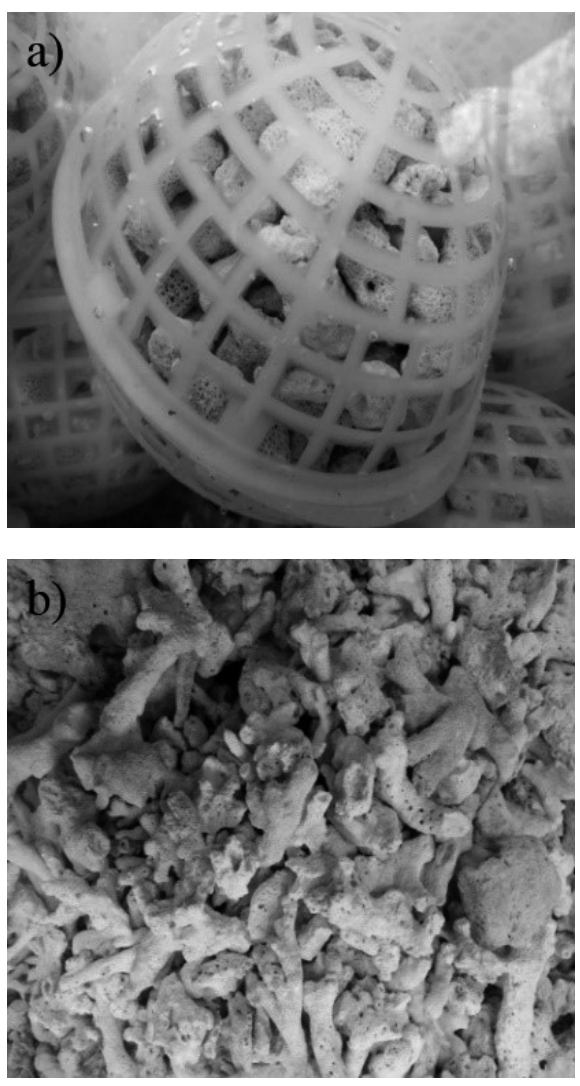

Fig. S1 a) Pictures of flow-separated ball $(\varnothing 10 \mathrm{~mm})$ filled with coral sand; b) Pictures of Coral sand (1 $\mathrm{mm} \sim 3 \mathrm{~mm}$ of effective particle size).

were packed (Fig. S1a), of which specific gravity was $0.91-0.93 \mathrm{~g} / \mathrm{cm}^{3}$. In addition, the abandoned coral sands with an effective particle size of 1-3 cm were filled in flow-separated balls (Fig. S1b), which came from the process of infrastructure construction of an island of the Paracel Islands, China.

The domestic sewage was elevated into a head tank after filtration by wire screen ( 40 mesh). The quality of domestic sewage in the head tank is shown in Table 1. The average concentrations of $\mathrm{COD}, \mathrm{TN}$ and $\mathrm{NH}_{4}{ }^{+} \mathrm{N}$ in inflow of the FSBR were $491 \mathrm{mg} / \mathrm{L}, 57.4 \mathrm{mg} / \mathrm{L}$ and $49.5 \mathrm{mg} / \mathrm{L}$, respectively.

\section{Startup and Operational Conditions}

During start-up, the FSBR feed with domestic sewage was first run as a sequencing batch reactor for 6 days. Subsequently, the FSBR was operated as a continuous flow reactor. The continuous flow periods were divided into 4 stages, of which the main operating parameters are shown in Table 2. In stage 1, when the FSBR was under startup conditions, the hydraulic retention time was gradually decreased and the ratio of air to water maintained a low value (15:1), which was beneficial to the growth of biofilms. From stage 2 to stage 4 , the hydraulic retention time was controlled to $12 \mathrm{~d}$ or $16 \mathrm{~d}$ and the ratio of air to water was gradually increased in order to study the effect of the ratio of air to water on biological nitrogen removal in the FSBR. The water qualities of inflow and effluent were measured twice a day from day 1 to day 69 or once a day from day 70 to day 110 , including the concentrations of $\mathrm{COD}, \mathrm{TN}, \mathrm{NH}_{4}^{+}-\mathrm{N}, \mathrm{NO}_{3}^{-}-\mathrm{N}$, $\mathrm{NO}_{2}^{-}-\mathrm{N}$ and $\mathrm{DO}$, as well as $\mathrm{pH}$ value and water temperature.

\section{Physicochemical Properties of Coral Sand}

The microstructure and elemental composition of coral sand were measured by the scanning electron microscopy (SEM) equipped with energy disperse spectroscopy (EDS) (Quanta 250FEG, FEI, USA). The acceleration voltage of SEM (HV) was 15.00 $\mathrm{KV}$, and the energy of EDS was $0.00 \sim 6.00 \mathrm{KeV}$. The phase composition of coral sand was measured by X-ray diffractometer (XRD) (D8 advance, Brucker, Germany).

\section{Determining Microbial Biomass}

Microbial aggregate in FSBR are classified into three forms, including suspended sludge, loosely attached biofilm and tightly attached biofilm. Suspended sludge concentration (in $\mathrm{mg} / \mathrm{L}$ ) was measured by the standard method [11]. The amounts of loosely attached biofilm and tightly attached biofilm were measured according to the procedures of Delatolla et al. [12]. Coral sand was rinsed 4 times with pure water and the rinsing fluids were collected, in which suspended solids were regarded as the loosely attached biofilm. Subsequently, the tightly attached biofilm sand was peeled off from the surface of coral sand with $0.1 \mathrm{~N} \mathrm{NaOH}$ solution by water bath oscillation at $80^{\circ} \mathrm{C}$. The amounts of loosely attached biofilm and tightly attached biofilm biomass were expressed as $\mathrm{mg} / \mathrm{g}$, respectively. They were also expressed as $\mathrm{mg} / \mathrm{L}$ with the conversion coefficient, which was calculated as follows.

Conversion coefficient $=\rho \times(1-m) \times A \times 10^{3}$

Table 1. Inflow water quality of the FSBR.

\begin{tabular}{|c|c|c|c|c|c|c|c|}
\hline Index & $\begin{array}{c}\mathrm{COD} \\
(\mathrm{mg} / \mathrm{L})\end{array}$ & $\begin{array}{c}\mathrm{TN} \\
(\mathrm{mg} / \mathrm{L})\end{array}$ & $\begin{array}{c}\mathrm{NH}_{4}^{+}-\mathrm{N} \\
(\mathrm{mg} / \mathrm{L})\end{array}$ & $\begin{array}{c}\mathrm{NO}_{3}^{-}-\mathrm{N} \\
(\mathrm{mg} / \mathrm{L})\end{array}$ & $\mathrm{pH}$ & $\mathrm{C} / \mathrm{N}$ & $\mathrm{T}\left({ }^{\circ} \mathrm{C}\right)$ \\
\hline Range value & $125-1008$ & $15.7-95.7$ & $9.3-77.4$ & $0.08-0.88$ & $6.55-7.78$ & $2.88-21.78$ & $12.1-31.9$ \\
\hline Average value & 491 & 57.4 & 49.3 & 0.33 & 7.15 & 8.94 & 21.3 \\
\hline
\end{tabular}


Table 2. Main operational parameters at different stages.

\begin{tabular}{|c|c|c|c|c|c|}
\hline Stage & Runtime (d) & Duration (d) & Flowrate (L/h) & Hydraulic retention time (h) & Air water ratio \\
\hline \multirow{4}{*}{1} & $7-8$ & 2 & 12 & 48 & \\
\cline { 2 - 6 } & $9-10$ & 2 & 24 & 24 & \multirow{3}{*}{15,1} \\
\cline { 2 - 6 } & $11-12$ & 2 & 36 & 16 & \\
\cline { 2 - 6 } & $13-14$ & 2 & 48 & 12 & 15,1 \\
\hline 2 & $15-32$ & 18 & 48 & 16 & 20,1 \\
\hline 3 & $33-48$ & 16 & 36 & 16 & 25,1 \\
\hline 4 & $49-110$ & 62 & 36 & & \\
\hline
\end{tabular}

...where $\rho$ is the density of coral sand $\left(\mathrm{g} / \mathrm{cm}^{3}\right)$, which is $2.88 \mathrm{~g} / \mathrm{cm}^{3}$; $\mathrm{m}$ is the clearance ratio among flow-separated balls, which is around 0.38; and $\mathrm{A}$ is the filling rate of coral sand in flow-separated ball, which is about 0.30 .

\section{Calculating SND Ratio}

The effect of microbial assimilation and cell lysis on the concentration of $\mathrm{NH}_{4}^{+}-\mathrm{N}$ was ignored in the process of calculating SND rate [5]. The calculation formula was as follows:

$$
S N D \%=\left(1-\frac{N O_{X}^{-} \text {produced }}{N H_{4}^{+} \text {removed }}\right) \times 100 \%
$$

...where $\mathrm{NO}_{\mathrm{x}}^{-}$produced is the difference between the sum of concentrations of $\mathrm{NO}_{2}^{-}-\mathrm{N}$ and $\mathrm{NO}_{3}^{-}-\mathrm{N}$ in effluent and inflow. $\mathrm{NH}_{4}^{+}$removed is the difference of concentrations of $\mathrm{NH}_{4}^{+}-\mathrm{N}$ in inflow and effluent.

\section{Microbial Community Analysis}

\section{DNA Extraction}

During stable operation (day 92), the samples of suspended sludge, loosely attached biofilm and tightly attached biofilm in the three reaction regions were collected, respectively. DNA was extracted by soil genomic DNA extraction kit (Tiangen Biochemical Technology Co., Ltd., Beijing, China). Then the DNA extract was stored at $-20^{\circ} \mathrm{C}$.

\section{PCR Amplification and High-Throughput Sequencing}

DNA samples were amplified by PCR using primer set 338F (5/-ACTCCTACGGG AGGCAGCAG-3/) and 806R (5/-GGACTACHVGGGTWTCTAAT-3/) for the V3-V4 region of $16 \mathrm{~S}$ rRNA gene. The $20 \mu \mathrm{L}$ mixture was used to perform PCR reaction, containing $4 \mu \mathrm{L}$ 5_FastPfu Buffer, $2 \mu \mathrm{L}$ dNTPs $(2.5 \mathrm{mM}), 0.8 \mu \mathrm{L}$ each primer $(5 \mu \mathrm{M}), 0.4 \mu \mathrm{L}$ of FastPfu polymerase, $0.2 \mu \mathrm{L}$ BSA and $10 \mathrm{ng}$ of template DNA. The PCR was performed in a GeneAmp_9700 (Applied
Biosystems, U.S.) with the following steps: $95^{\circ} \mathrm{C}$ for $3 \mathrm{~min}$, followed by 27 cycles of denaturing at $94^{\circ} \mathrm{C}$ for $30 \mathrm{~s}$, annealing at $55^{\circ} \mathrm{C}$ for $30 \mathrm{~s}$, and extension at $72^{\circ} \mathrm{C}$ for $45 \mathrm{~s}$, followed by a final extension at $72^{\circ} \mathrm{C}$ for 10 min. The PCR products were sequenced on an
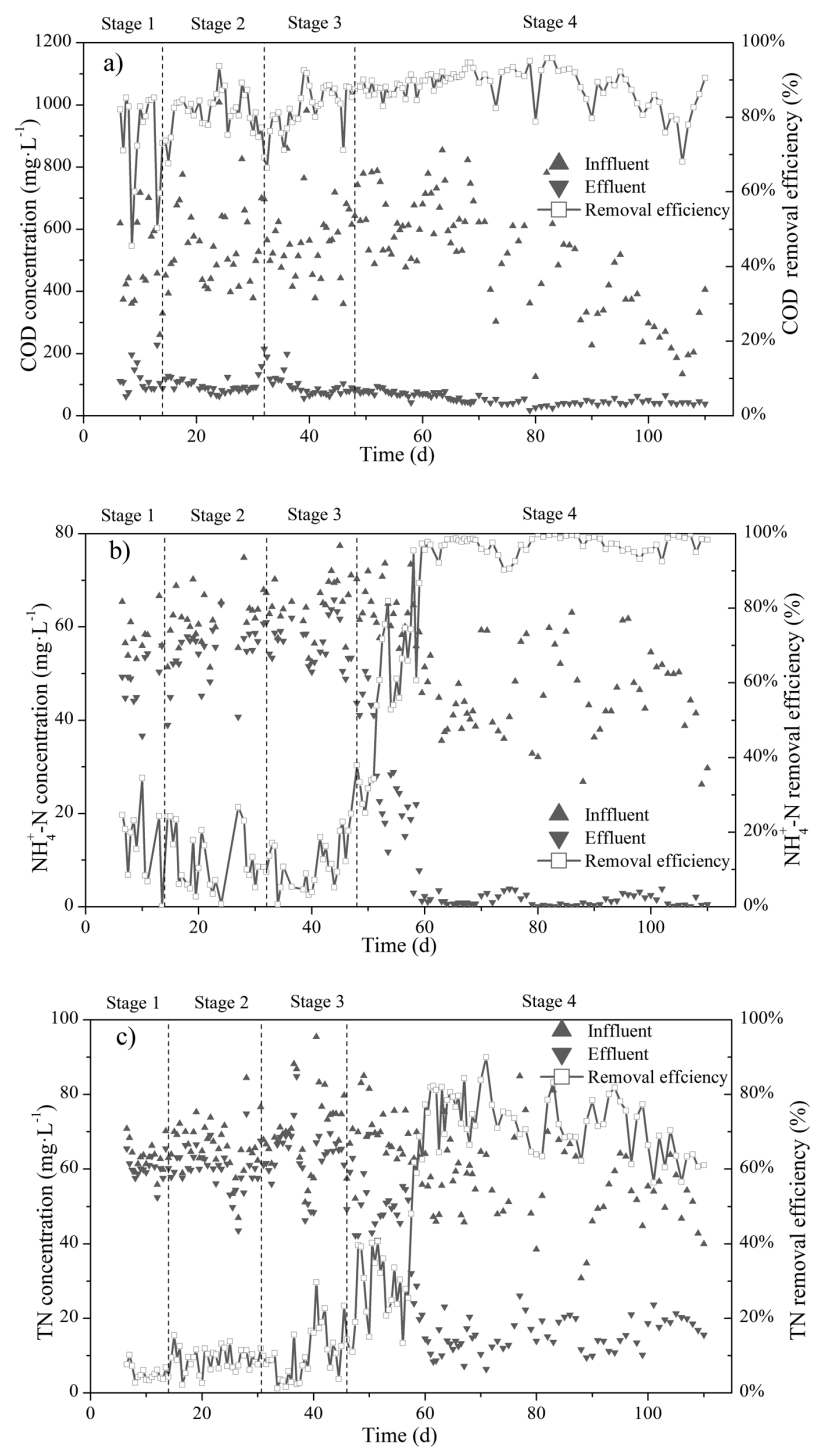

Fig. 2. Water quality changes of influx and efflux and removal efficiencies of pollutants: a) COD, b) $\mathrm{NH}_{4}^{+}-\mathrm{N}$, c) TN. 
Illumina MiSeq PE300 platform according to the standard protocols. The raw sequences were deposited to the NCBI (serial number SPR123034).

\section{Other Analytical Methods}

The DO concentration and $\mathrm{pH}$ value in liquid phase was examined with a DO analyzer (Pro20, YSI, Ohio,
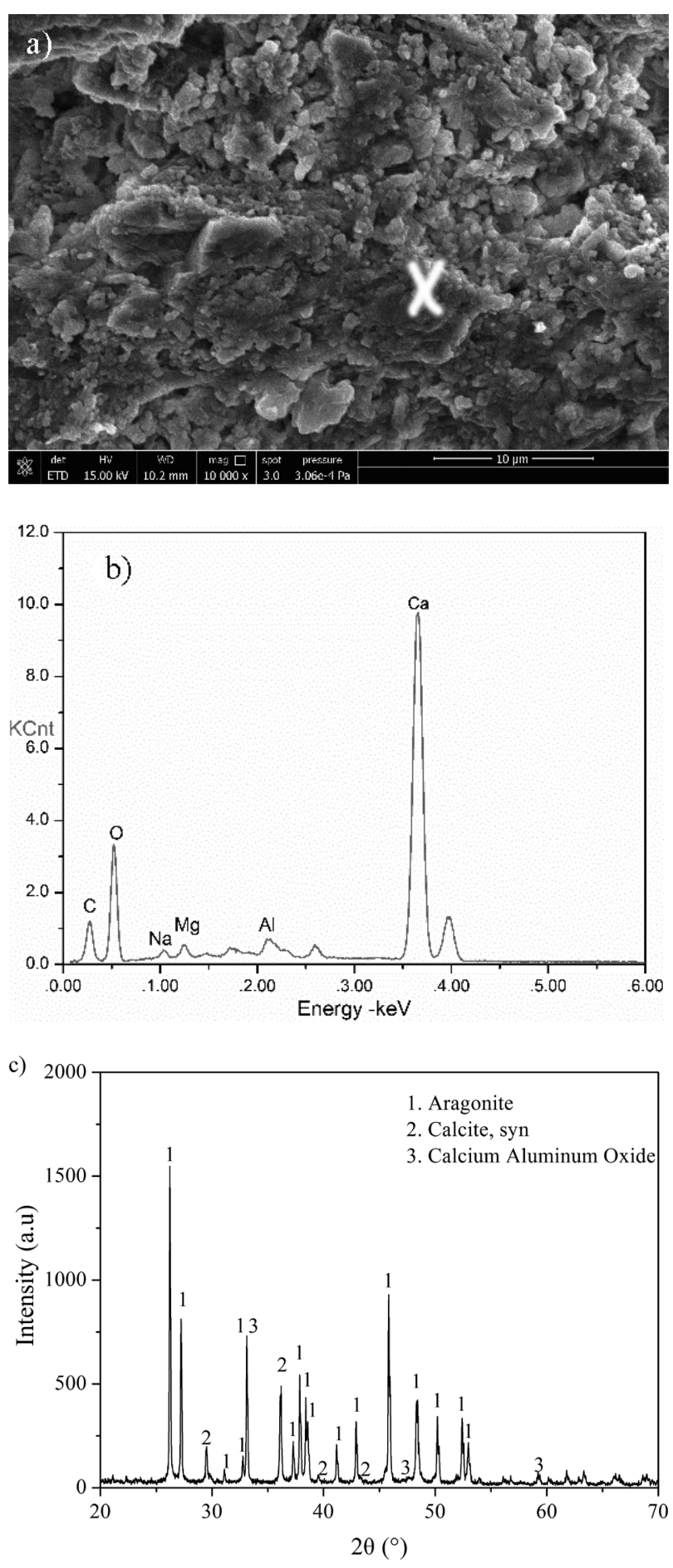

Fig. S2 a) SEM photograph of coral sand; b) EDS analysis of the point marked in the SEM image of coral sand; c) XRD spectra of coral sand.

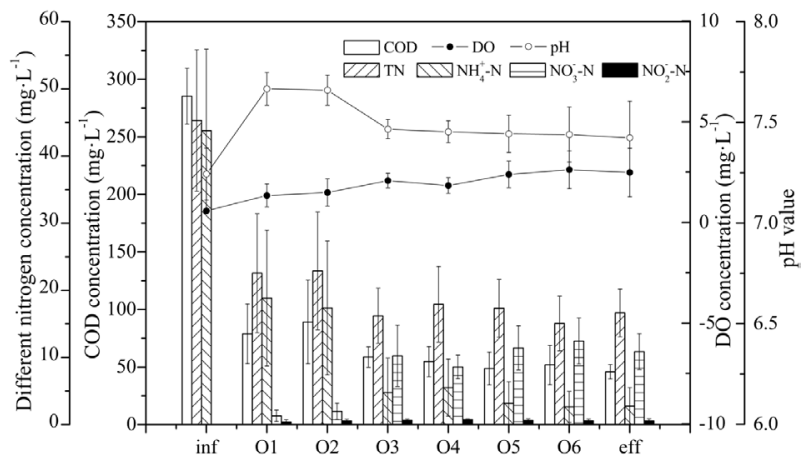

Fig. 3. Concentration of pollutants along flow direction.

USA) and a pH meter (PHBJ-260, Raytheon, Shanghai), respectively. The concentrations of $\mathrm{COD}, \mathrm{NH}_{4}^{+}-\mathrm{N}$, $\mathrm{NO}_{2}^{-}-\mathrm{N}, \mathrm{NO}_{3}^{-}-\mathrm{N}$ and $\mathrm{TN}$ were measured according to the standard methods [11].

\section{Results and Discussion}

\section{Physicochemical Oroperties of Coral Sand}

As shown in the SEM image (Fig. S2a), the coral sand had a rough surface and porous structure, which should be beneficial to the attached growth of microorganisms. With the analysis of EDS (Fig. S2b), the main elements of coral sand were $\mathrm{Ca}, \mathrm{C}$ and $\mathrm{O}$. Furthermore, the mass percentages of $\mathrm{Ca}, \mathrm{C}$ and $\mathrm{O}$ in coral sand were $22.02 \% \sim 33.89 \%, 10.63 \% \sim 10.97 \%$ and $53.00 \% \sim 63.97 \%$, respectively. As shown in the XRD spectra (Fig. S2c), the main phase composition of coral sand was metastable aragonite $\left(\mathrm{CaCO}_{3}\right)$, of which the other phase compositions included a small amount of stable calcite $\left(\mathrm{CaCO}_{3}\right)$ and tricalcium aluminate $\left(\mathrm{Ca}_{3} \mathrm{Al}_{2} \mathrm{O}_{6}\right)$. Both the calcite $\left(\mathrm{CaCO}_{3}\right)$ and tricalcium aluminate $\left(\mathrm{Ca}_{3} \mathrm{Al}_{2} \mathrm{O}_{6}\right)$ had good mechanical strengths, which might play key roles in the structural strength of coral sand. The results indicated that coral sand had good physicochemical properties as a biofilm carrier.

\section{Removal Efficiency of Pollutants}

As shown in Fig. 2, the removal efficiency of COD increased with the increase of air water ratio (from stage 2 to stage 4). After day 65, the removal efficiency of COD was stable $(88.16 \% \pm 5.87 \%)$. In the initial phase of the start-up, the removal efficiencies of $\mathrm{NH}_{4}^{+}-\mathrm{N}$ and TN were low. From day 40 to day 60 , the removal efficiencies increased rapidly. After day 60 , the removal efficiencies were stable at the same time. The concentrations of $\mathrm{NH}_{4}^{+}-\mathrm{N}$ and $\mathrm{TN}$ in effluent were $1.25 \pm 1.06 \mathrm{mg} / \mathrm{L}$ and $14.39 \pm 4.37 \mathrm{mg} / \mathrm{L}$, respectively. Meanwhile, the removal efficiencies of $\mathrm{NH}_{4}^{+}-\mathrm{N}$ and $\mathrm{TN}$ were $97.21 \pm 2.37 \%$ and $74.68 \pm 6.49 \%$, respectively. In addition, the SND rate was $80.50 \pm 9.38 \%$. Importantly, there was a strong positive correlation between the removal efficiencies 


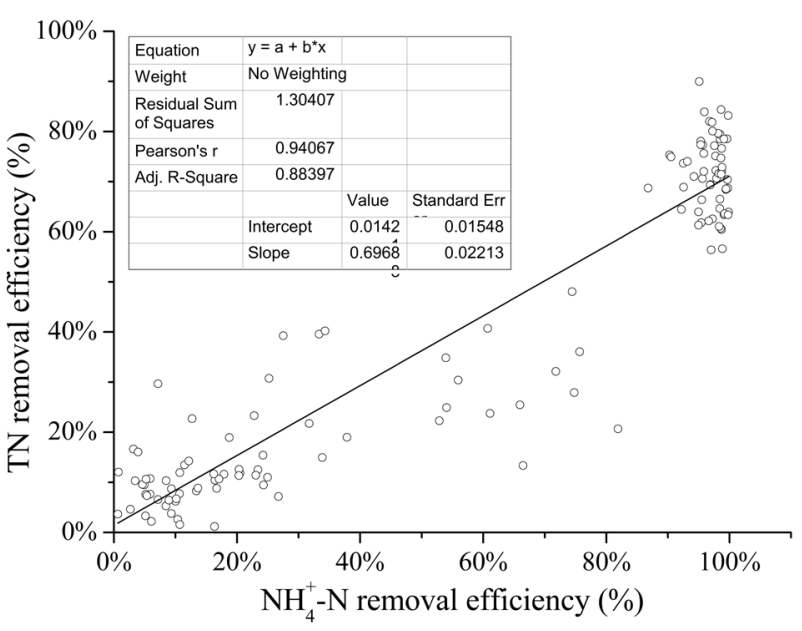

Fig. S3. Correlation between removal rates of $\mathrm{NH} 4+-\mathrm{N}$ and TN.

of $\mathrm{NH}_{4}^{+}-\mathrm{N}$ and $\mathrm{TN}\left(\mathrm{r}_{\mathrm{p}}=0.941, \mathrm{p}<0.05\right)$ (Fig. S3), indicating an obvious SND phenomenon. In stage 2, both the DO concentrations and $\mathrm{pH}$ values in effluent continued to decrease because of the lower air:water ratio (Fig. S4a). In stage 3 they continued to increase because of the higher air:water ratio. In stage 4 , the DO concentrations in effluent were greater than $2 \mathrm{mg} / \mathrm{L}$, and the $\mathrm{pH}$ values were maintained at between 7.25 and 7.75. After day 60, the higher DO concentration in effluent was corresponding to the higher $\mathrm{pH}$ value. Meanwhile, there was a strong positive correlation between the DO concentration and the $\mathrm{pH}$ value in effluent $\left(r_{p}=0.645, p<0.05\right)$ (Fig. S4b). The results indicated that the FSBR had a good performance of SND, which could effectively compensate for the alkalinity consumption in nitrification process.

It was noteworthy that the phenomenon of alternating-accumulation of $\mathrm{NO}_{2}^{-}-\mathrm{N}$ and $\mathrm{NO}_{3}^{-}-\mathrm{N}$ occurred after day 40 (Fig. S5). From day 40 to day 59, the $\mathrm{NO}_{2}^{-}-\mathrm{N}$ concentration of effluent gradually increased. After day 60, the $\mathrm{NO}_{2}^{-}-\mathrm{N}$ concentration of effluent decreased rapidly, when the $\mathrm{NO}_{3}^{-}-\mathrm{N}$ concentration increased. This phenomenon suggested that nitriteoxidizing bacteria (NOB) had be effectively enriched in the FSBR. The results indicated that ammonia-oxidizing bacteria (AOB) might be enriched earlier than NOB.

\section{Removal Efficiency of Pollutants Along Flow Direction}

The reaction area of the FSBR was divided into three reaction regions. In addition, six sampling points were set at equal distance in the reaction area, which were marked as $\mathrm{O} 1, \mathrm{O} 2, \mathrm{O} 3, \mathrm{O} 4, \mathrm{O} 5$, and $\mathrm{O} 6$ along the flow direction, respectively. Namely, there were two sampling points in each reaction region. From day 70 to day 90 , the removal efficiency of pollutants along the flow direction of the FSBR was investigated (Fig. 3 and Table 3). As shown in Fig. 3 and Table 3, the removal of pollutants mainly occurred in the first reaction region. In the first region, the DO concentration in liquid phase was $1.49 \pm 0.07 \mathrm{mg} / \mathrm{L}$. The removal efficiencies of COD, $\mathrm{NH}_{4}^{+}-\mathrm{N}$ and $\mathrm{TN}$ were $68.74 \pm 12.48 \%, 60.32 \pm 15.63 \%$ and $49.50 \pm 9.29 \%$, respectively. Simultaneously, the SND rate was $90.73 \pm 7.65 \%$, suggesting that there was obvious SND in the first region. In the second region, the DO concentration in liquid phase was slightly increased $(1.83 \pm 0.05 \mathrm{mg} / \mathrm{L})$. The $\mathrm{NH}_{4}{ }^{+} \mathrm{N}$ concentration in liquid phase was further decreased when the concentrations of COD and TN were slightly decreased. At the same time, the SND rate was $34.05 \pm 15.21 \%$. Furthermore, the $\mathrm{pH}$ value of liquid phase in the second region was lower than that in the first region, suggesting that the nitrification in the second region consumed a lot of alkalinity. In the third region, the DO concentration of liquid phase was $2.62 \pm 0.14 \mathrm{mg} / \mathrm{L}$. In addition, the concentrations of $\mathrm{COD}, \mathrm{NH}_{4}^{+}-\mathrm{N}$ and $\mathrm{TN}$ in liquid phase were slightly decreased, when $\mathrm{NO}_{3}^{-}-\mathrm{N}$ concentration was slightly increased and $\mathrm{NO}_{2}^{-}-\mathrm{N}$ concentration was reduced to near zero. The above results indicated that the first region was an important area for carbonation reaction and SND reaction.

\section{Spatial Distribution Characteristics of Microbial Biomass}

There were three forms of microbial aggregate in the FSBR, including suspended sludge, loosely attached biofilm and tightly attached biofilm. From day 70 to day 90 , the spatial distribution characteristics of different forms of microbial aggregate in the FSBR
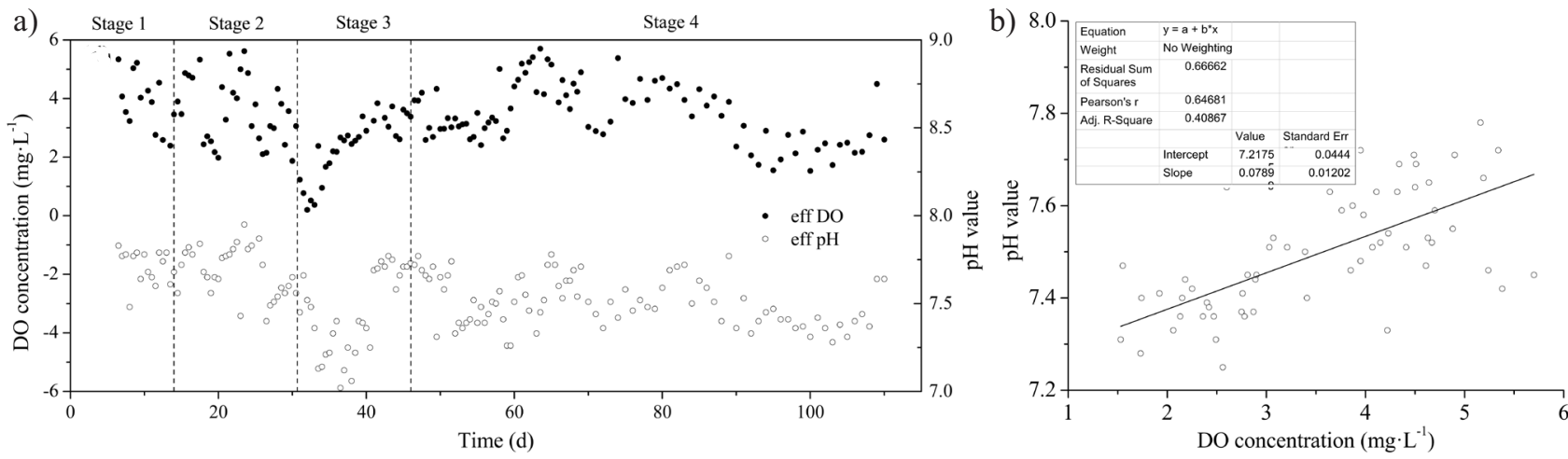

Fig. S4 a) DO concentration and $\mathrm{pH}$ value in effluent; b) Correlation between DO concentration and $\mathrm{pH}$ value in effluent. 


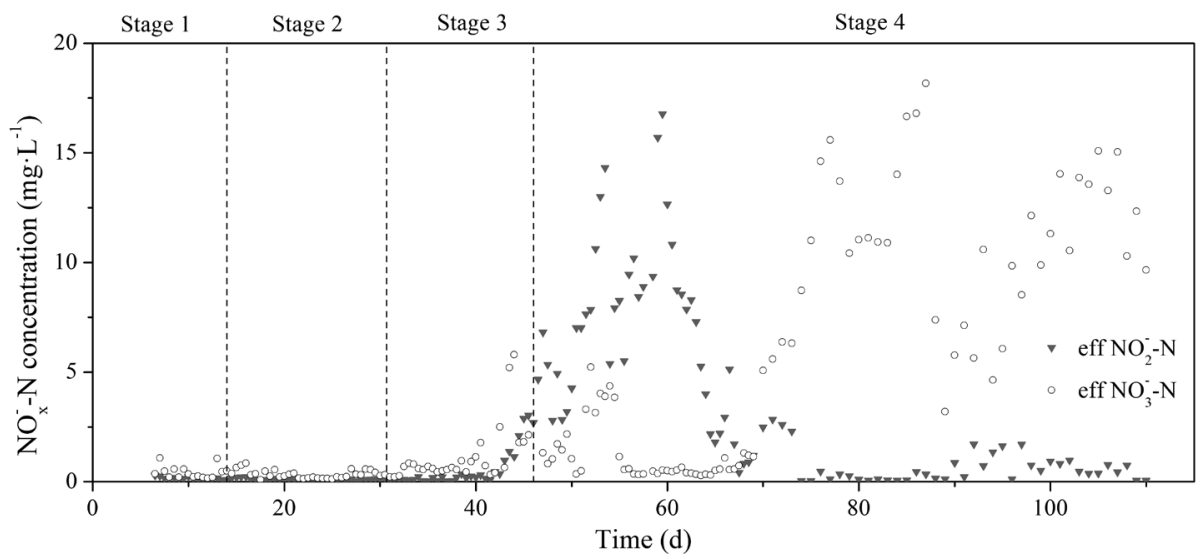

Fig. S5 NOx-N concentration of effluent.

were investigated (Fig. 4). As shown in Fig. 4, the total biomass concentration and the biomass concentrations of three forms of microbial aggregate in the three reaction regions all decreased along the flow direction. The total biomass concentrations in the three regions along the flow direction were $7525.97 \pm 2084.55 \mathrm{mg} / \mathrm{L}, \quad 3627.94 \pm 1173.07 \mathrm{mg} / \mathrm{L}$ and $2941.35 \pm 1032.59 \mathrm{mg} / \mathrm{L}$, respectively. The total biomass concentration in the first region was 2.07 and 2.59 times of those in the second and third regions, respectively. The biomass concentrations of tightly attached biofilm in the three regions along the flow direction were $4731.29 \pm 1178.56 \mathrm{mg} / \mathrm{L}, \quad 2309.20 \pm 751.23 \mathrm{mg} / \mathrm{L}$ and $1829.09 \pm 494.04 \mathrm{mg} / \mathrm{L}$, respectively, which were $62.87 \%, 63.65 \%$ and $62.19 \%$ of the corresponding total biomass concentrations. The results indicated that the tightly attached biofilm was an important microbial aggregate in the reactor. The biomass concentrations of loosely attached biofilm in the three regions along the flow direction were $1964.26 \pm 651.17 \mathrm{mg} / \mathrm{L}$, $1029 \pm 354.95 \mathrm{mg} / \mathrm{L}$ and $1022.39 \pm 479.33 \mathrm{mg} / \mathrm{L}$, respectively. The concentrations of suspended sludge (SS) in the three regions along the flow direction were $\quad 830.43 \pm 252.82 \mathrm{mg} / \mathrm{L}, \quad 289.75 \pm 66.89 \mathrm{mg} / \mathrm{L} \quad$ and $89.88 \pm 59.22 \mathrm{mg} / \mathrm{L}$, respectively. The phenomenon of the rapid reduction of SS along the flow direction illustrated that the FSBR could save a secondary settling tank due to the effect of flow separation.

\section{Microbial Community Structure}

The microbial community structures of the three forms of microbial aggregate in the three reaction regions were analyzed by high-throughput sequencing. From Table S1, the effective sequence numbers of community in the three forms of microbial aggregate of the three regions were 30064-44808, when the values of OUT were 973-1222 and the values of coverage were greater than $99 \%$. Therefore, the results reflected the majority of microbial communities. In addition, the indexes of ACE, Chao, Shannon and Simpson illustrated that the richness and diversity of the microbial population of suspended sludge, loosely attached biofilm and tightly attached biofilm in the second and third regions were slightly more than those in the first region.

The percentages of community abundance on Genus level in the three reaction regions were shown in Fig. 5. In the first region, the main bacteria at

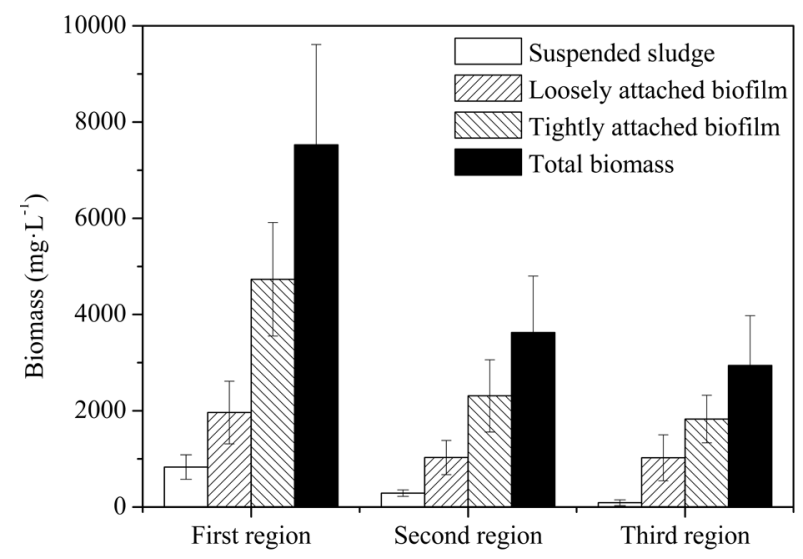

Fig. 4. Microbial biomass in the three regions of the FSBR.

Table 3. Removal efficiencies of pollutants in different reaction regions.

\begin{tabular}{|c|c|c|c|}
\hline Index & $\mathrm{COD}$ & $\mathrm{NH}_{4}^{+}-\mathrm{N}$ & $\mathrm{TN}$ \\
\hline First region & $68.74 \pm 12.48 \%$ & $60.32 \pm 15.63 \%$ & $49.50 \pm 9.29 \%$ \\
\hline Second region & $12.09 \pm 9.96 \%$ & $27.11 \pm 10.81 \%$ & $10.96 \pm 7.03 \%$ \\
\hline Third region & $1.04 \pm 0.24 \%$ & $6.51 \pm 3.96 \%$ & $6.29 \pm 4.44 \%$ \\
\hline
\end{tabular}




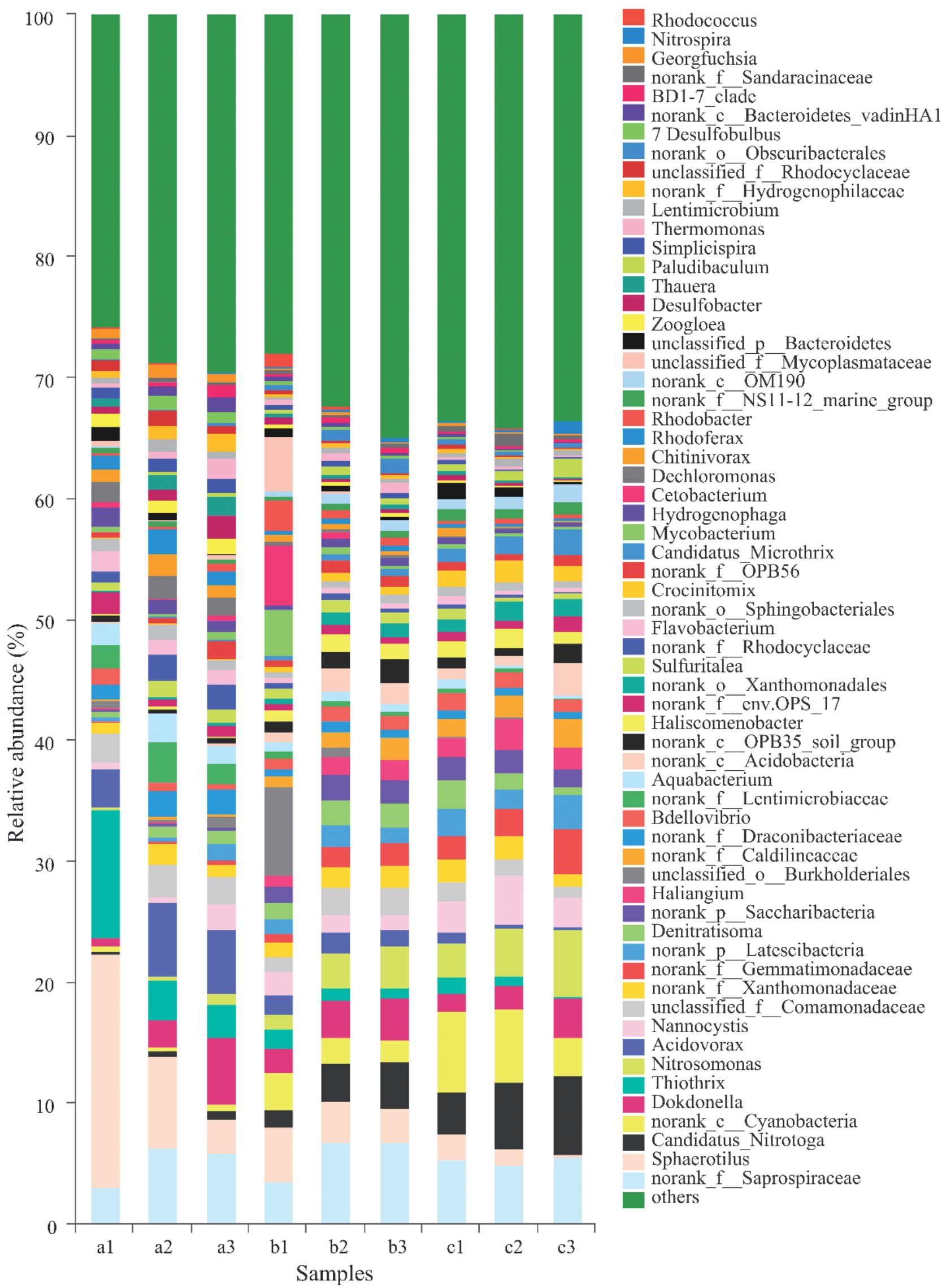

Fig. 5. Percentages of community abundance on genus level in different microbial aggregates of the three reaction regions (a, b and $\mathrm{c}$ represented the first, second and third reaction region, respectively; 1, 2 and 3 represented suspended sludge, loosely attached biofilm and tightly attached biofilm, respectively). 


\begin{tabular}{|c|c|c|c|c|c|c|c|c|c|c|c|c|c|c|c|c|c|c|c|c|c|}
\hline 3 & $\stackrel{?}{=}$ & $\stackrel{7}{0}$ & సิ & $\stackrel{7}{0}$ & त̂ & $\frac{7}{0}$ & $\frac{n}{0}$ & $\stackrel{8}{\circ}$ & $\stackrel{n}{\mathfrak{c}}$ & $\mid \begin{array}{l}0 \\
0 \\
0\end{array}$ & $\exists$ & $\begin{array}{l}\infty \\
\dot{a} \\
i\end{array}$ & $\vec{n}$ & $\stackrel{\text { ते }}{\mathrm{m}}$ & $\begin{array}{ll} \\
0 \\
0\end{array}$ & $\underset{i}{\underset{i}{J}}$ & \begin{tabular}{|l|} 
\\
$\stackrel{2}{-}$
\end{tabular} & $\underset{m}{ \pm}$ & $\stackrel{m}{\sim}$ & $\stackrel{m}{=}$ & $\stackrel{8}{8}$ \\
\hline ช & I & $\frac{\infty}{0}$ & ? & \begin{tabular}{l}
$\infty$ \\
\multirow{1}{*}{}
\end{tabular} & ñ & స̦ & $\frac{\infty}{0}$ & $\stackrel{0}{\stackrel{0}{0}}$ & 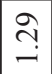 & $\begin{array}{l}\overrightarrow{0} \\
0 \\
0\end{array}$ & $\stackrel{0}{\stackrel{0}{0}}$ & $\begin{array}{l}\delta \\
\dot{+} \\
\dot{+}\end{array}$ & $\begin{array}{l}\stackrel{n}{n} \\
i n\end{array}$ & $\stackrel{\circ}{\circ}$ & $\begin{array}{l}m \\
\stackrel{0}{0}\end{array}$ & $\begin{array}{l}8 \\
\dot{+}\end{array}$ & $\begin{array}{l}\vec{b} \\
i\end{array} \mid$ & $\begin{array}{l}\infty \\
\stackrel{0}{0}\end{array}$ & $\stackrel{\infty}{\infty}$ & $\underline{I}$ & ?̊ \\
\hline$\vec{v}$ & $\stackrel{\bullet}{:}$ & $\begin{array}{l}\tilde{n} \\
\tilde{0}\end{array}$ & ?̊ & $\stackrel{1}{0}$ & t) & త్ & $\overline{\tilde{O}}$ & 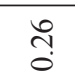 & $\begin{array}{c}\hat{\tilde{n}} \\
\mathrm{i}\end{array}$ & \begin{tabular}{|l|} 
\\
0 \\
0
\end{tabular} & $\stackrel{m}{0}$ & $\begin{array}{l}\infty \\
\stackrel{i}{i}\end{array} \mid$ & $\stackrel{\text { fे }}{r}$ & $\stackrel{\sim}{\stackrel{n}{n}}$ & $\stackrel{\leftrightarrow}{\stackrel{2}{a}}$ & $\begin{array}{l}\hat{n} \\
\text { in }\end{array}$ & $\begin{array}{l}3 \\
-\end{array}$ & : & $\stackrel{g}{g}$ & $\stackrel{\leftrightarrow}{\circ}$ & $\stackrel{J}{0}$ \\
\hline 3 & $\stackrel{m}{i}$ & $\mid \begin{array}{c}\infty \\
\cdots \\
0\end{array}$ & $\begin{array}{l}0 \\
0 \\
0\end{array}$ & $\hat{\sigma}$ & 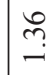 & 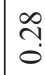 & ஸे & $\begin{array}{l}\text { స̦ } \\
\text { o }\end{array}$ & $\stackrel{0}{\circ}$ & 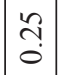 & $\hat{\widehat{o}}$ & $\vec{n}$ & $\begin{array}{l}\infty \\
\infty \\
\dot{n}\end{array}$ & $\hat{n}$ & $\frac{2}{0}$ & $\stackrel{\infty}{\stackrel{-}{\longrightarrow}}$ & $\left|\begin{array}{c}\infty \\
0 \\
\hdashline \\
-\end{array}\right|$ & $\stackrel{t}{\stackrel{t}{I}}$ & $\stackrel{\mathbb{I}}{\stackrel{2}{*}}$ & 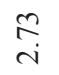 & $\vec{\sigma}$ \\
\hline$\tilde{\Omega}$ & $\begin{array}{l}\infty \\
\stackrel{\sim}{i}\end{array}$ & $\vec{f}$ & $\begin{array}{l}\infty \\
0 \\
0\end{array}$ & $\stackrel{n}{o}$ & $\stackrel{F}{Z}$ & $\begin{array}{l}0 \\
\text { ? } \\
\end{array}$ & ? & ' & $\underset{i}{\stackrel{N}{i}}$ & 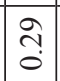 & ণे & $\tilde{\delta}$ & $\underset{\text { iे }}{\text { oे }}$ & $\begin{array}{l}n \\
\dot{n}\end{array}$ & $\underset{-}{8}$ & 守 & $\stackrel{q}{\stackrel{g}{-}}$ & $\stackrel{\vec{i}}{i}$ & $\stackrel{\infty}{\stackrel{\infty}{\longrightarrow}}$ & $\begin{array}{l}\infty \\
\stackrel{n}{n}\end{array}$ & त̣̂ \\
\hline $\overrightarrow{0}$ & $\stackrel{\text { f }}{-}$ & $\begin{array}{c}n \\
m \\
0\end{array}$ & $\mid \begin{array}{l}\infty \\
n \\
0\end{array}$ & $\begin{array}{l}0 \\
\infty \\
0 \\
0\end{array}$ & ñ & ઼ָ & 恶 & 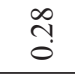 & 导 & $\begin{array}{c}m \\
\tilde{o} \\
0\end{array}$ & $\stackrel{d}{\Delta}$ & 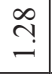 & $\underset{-}{\vec{F}}$ & $\underset{i}{8}$ & 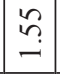 & $\stackrel{\partial}{-}$ & Jे & $\underset{m}{\bar{m}}$ & $\begin{array}{l}\infty \\
\infty \\
0 \\
0\end{array}$ & $\stackrel{\text { I }}{-}$ & $\stackrel{0}{0}$ \\
\hline 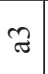 & $\underset{i}{\stackrel{i}{i}}$ & $\begin{array}{l}\infty \\
\\
0\end{array}$ & $\begin{array}{l}n \\
\infty \\
0 \\
0\end{array}$ & $\stackrel{n}{\rightarrow}$ & $\begin{array}{l}\tilde{\sigma} \\
\text { in }\end{array}$ & : & $\stackrel{\overbrace{}}{\stackrel{2}{n}}$ & $\stackrel{2}{\stackrel{0}{0}}$ & ô. & \begin{tabular}{|l|} 
\\
+ \\
\end{tabular} & $\stackrel{\infty}{+}$ & $\begin{array}{l}2 \\
\infty \\
0\end{array}$ & 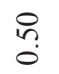 & 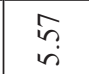 & $\begin{array}{l}\stackrel{i}{i} \\
\vec{i}\end{array}$ & $\underset{\vec{i}}{\Delta}$ & I & $n$ & 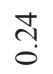 & $\underset{i}{\stackrel{i}{i}}$ & , \\
\hline$\approx$ & $\underset{\sim}{\stackrel{i}{r}}$ & $\begin{array}{l}\tilde{\delta} \\
i \\
i\end{array}$ & $\stackrel{(}{\exists}$ & $\stackrel{\overbrace{}}{i}$ & $\begin{array}{l}\text { to } \\
\text { in }\end{array}$ & $\stackrel{\overbrace{}}{\overbrace{}}$ & $\underset{-}{\sigma}$ & $\stackrel{\infty}{\underset{\sim}{\sim}}$ & $\begin{array}{l}\infty \\
\infty \\
0 \\
0\end{array}$ & $\mid \begin{array}{l}\infty \\
\infty \\
-1\end{array}$ & $\stackrel{\cong}{=}$ & $\underset{0}{\mathbb{Z}}$ & $\stackrel{1}{0}$ & 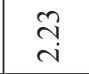 & $\mid \begin{array}{c}\stackrel{i}{1} \\
\text { ri }\end{array}$ & के & , & $\stackrel{n}{\tilde{c}}$ & તి & $\underset{n}{\stackrel{ \pm}{n}}$ & \\
\hline$\vec{\pi}$ & $\underset{i}{\stackrel{i}{i}}$ & $\stackrel{\infty}{=}$ & nֶ. & $\stackrel{\infty}{\stackrel{\infty}{-}}$ & $\underset{m}{=}$ & $\stackrel{8}{0}$ & $\exists$ & $\bar{a}$ & $\begin{array}{l}0 \\
0 \\
0\end{array}$ & $\mid \begin{array}{c}\hat{\sigma} \\
-\end{array}$ & $\ddot{n}$ & $\stackrel{\odot}{\overrightarrow{0}}$ & $\stackrel{0}{0}$ & $\vec{i}$ & $\mid \begin{array}{l}n \\
0 \\
0\end{array}$ & f. & ' & $\stackrel{\infty}{\stackrel{0}{0}}$ & $\ddot{0}$ & $\stackrel{i}{i}$ & . \\
\hline 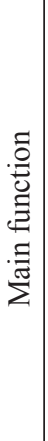 & 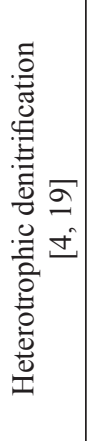 & 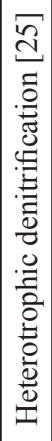 & 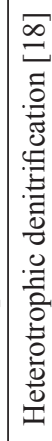 & 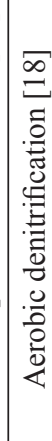 & 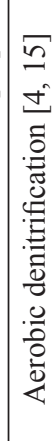 & 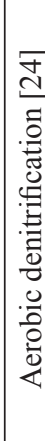 & 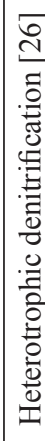 & 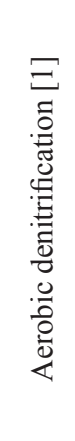 & 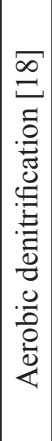 & 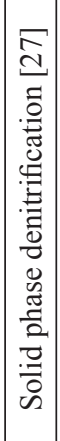 & 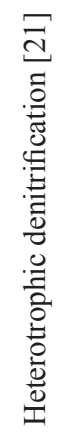 & 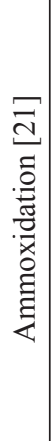 & 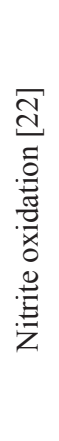 & 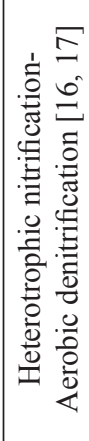 & 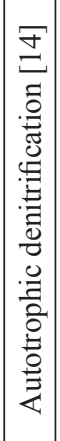 & 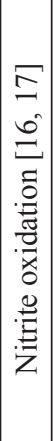 & 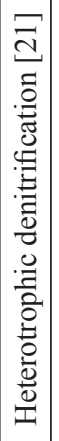 & 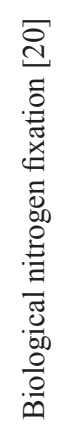 & 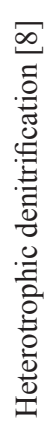 & 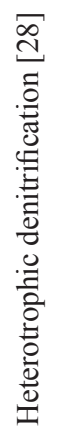 & 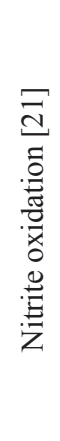 \\
\hline
\end{tabular}

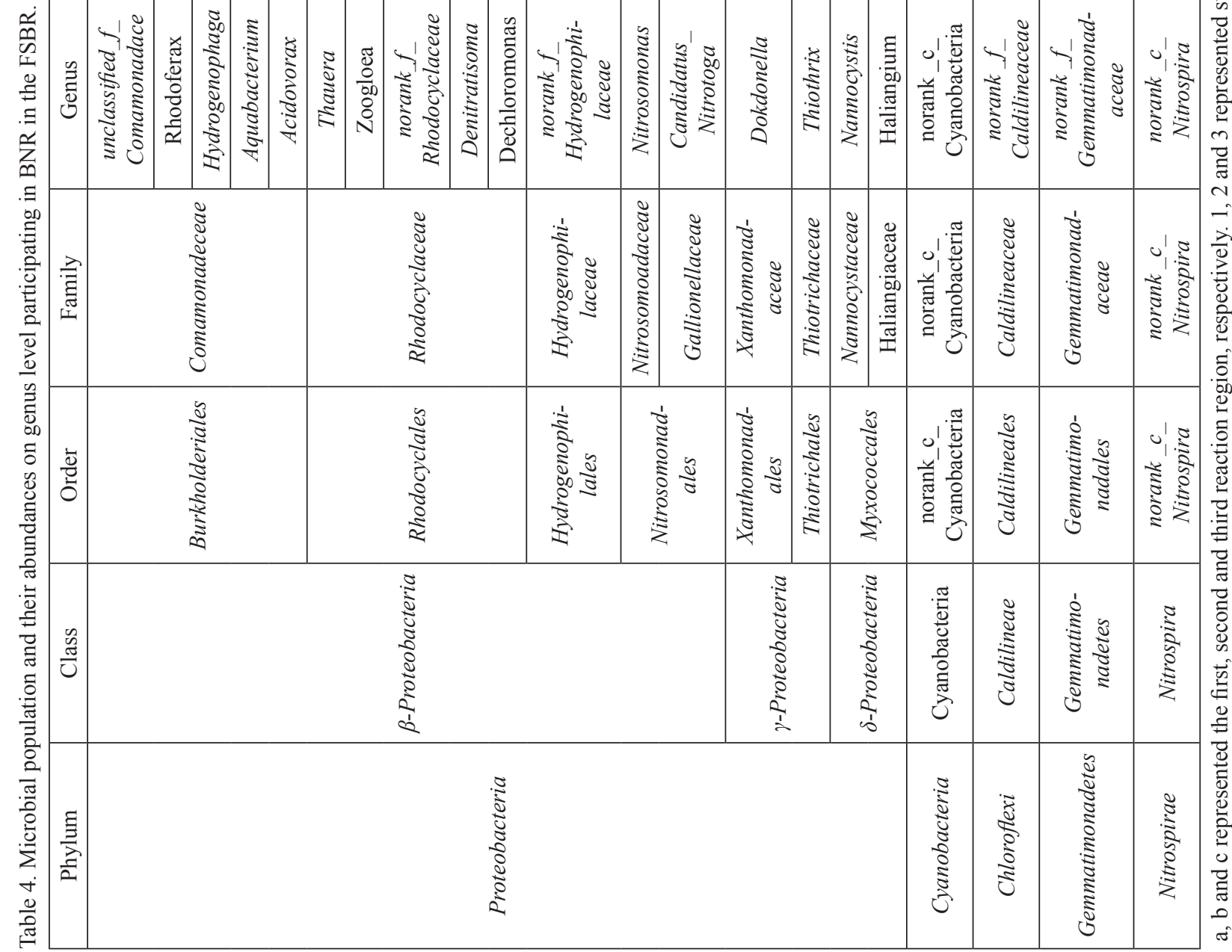


genus level in suspended sludge included Sphaerotilus (19.26\%), Thiothrix (10.55\%), Acidovorax (3.11\%), norank $f$ Saprospiraceae (3.09\%) and unclassified $f$ Comamonadaceae $(2.12 \%)$. The main bacteria at genus level in loosely attached biofilm included Sphaerotilus (7.59\%), norank_f_Saprospiraceae (6.26\%), Acidovorax (5.94\%), norank_f_Lentimicrobiaceae (3.38\%), unclassified_f_Comamonadaceae (3.24\%), Thiothrix (3.20\%), Aquabacterium (2.33\%) and Dokdonella $(2.23 \%)$. The main bacteria at genus level in tightly attached biofilm were norank_f_Saprospiraceae (5.85\%), Dokdonella (5.57\%), Acidovorax (5.02\%), Sphaerotilus (2.84\%), unclassified_f_Comamonadaceae $(2.72 \%)$ and Thiothrix $(2.72 \%)$. In these bacteria, Sphaerotilus, Thiothrix, Acidovorax, unclassified_f Comamonadaceae, Aquabacterium and Dokdonella all belonged to Proteobacteria. Both Sphaerotilus and Saprospiraceae were common microorganisms with organic substance degradation [13]. In the first region, the abundance of Sphaerotilus in suspended sludge was more than those in loosely attached biofilm and tightly attached biofilm. However, the abundance of norank_f $f_{-}$ Saprospiraceae in suspended sludge was lower than those in loosely attached biofilm and tightly attached biofilm. Thiothrix was an autotrophic denitrifying bacterium [14], which was abundant in suspended sludge of the first region. In the first region, the order of the Thiothrix abundance in the three forms of microbial aggregate was as follows: suspended sludge > loosely attached biofilm $>$ tightly attached biofilm. In addition, Acidovorax [4, 15], Dokdonella [16, 17], Aquabacterium [18] and unclassified_f_Comamonadaceae [19] are aerobic denitrifying bacteria. In the first region, their abundances in tightly attached biofilm and loosely attached biofilm were obviously more than that in suspended sludge. The results indicated that there were significant differences of the abundances of bacteria with organic substance degradation and/or BNR among in the three forms of microbial aggregate in the first region.

In the second and third regions, the microbial community structures of loosely attached biofilm and tightly attached biofilm were similar, which were different from that of suspended sludge. In the three forms of microbial aggregate in the different regions, the abundance variation along the flow direction of Sphaerotilus was consistent with the change of COD removal efficiency. The abundance variation along the flow direction of Norank_f_Saprospiraceae in the three forms of microbial aggregate was not obvious because Saprospiraceae could not only utilize organic substance in inflow, but also metabolize cell fragments [13]. (By the way, Cyanobacteria was a photosynthetic bacteria with nitrogen fixation performance [20]). In the third region, there was a great deal of norank_c Cyanobacteria in the three forms of microbial aggregate, suggesting that water quality had been significantly improved.

\section{Biotechnological Characterization of SND in FSBR}

In the study, domestic sewage was used as the influx. Therefore, there was a greater diversity of microbial communities taking part in BNR in the FSBR (Table 4). As shown in Table 4, the main aerobic AOB in FSBR was Nitrosomonas [21], and the main NOB included Candidatus nitrotoga [22], Nitrospira [21] and Nannocystis [16, 17]. In the three regions, the abundance of Nitrosomonas, Candidatus nitrotoga and Nitrospira in the three forms of microbial aggregate all increased along the flow direction. In the first region, the abundance of Nitrosomonas in suspended sludge, loosely attached biofilm and tightly attached biofilm were $0.19 \%, 0.44 \%$ and $0.89 \%$, respectively, suggesting that aerobic ammonia oxidation mostly occurred in tightly attached biofilm. Moreover, Nannocystis was an important NOB in the tightly attached biofilm of the first region, of which the abundance (2.14\%) was 4.19 times of that of Candidatus_nitrotoga and far more than that of Nitrospira. Compared with the above nitrifying bacteria, denitrifying bacteria had higher abundance and population diversity in the first region. These denitrifying bacteria mainly belonged to six families of Proteobacteria, such as Comamonadeceae, Rhodocyclaceae, Hydrogenophilaceae, Xanthomonadaceae, Thiotrichaceae and Haliangiaceae. In the first region, the sum of their abundances in suspended sludge, loosely attached biofilm and tightly attached biofilm were $27.08 \%, 27.47 \%$ and $27.06 \%$, respectively, which were $2.27,1.83$ and 1.78 times those in the second region and were 2.18, 2.72 and 3.23 times those in the third region. In addition, the total biomass in the first region was 2.07 and 2.56 times of that in the second and third regions, in which the amount of tightly attached biofilm was $62.87 \%$ (Fig. 4). The above results indicated that the tightly attached biofilm in the first region was a key microbial aggregate of SND reaction.

According to the types of electron donors, denitrification can be divided into autotrophic denitrification (AD) and heterotrophic denitrification (HD). Thiothrix is sulfide-autotrophic denitrifying bacteria, which utilizes sulfide or sulfur-containing organics as electron donor and nitrite or nitrate as electron acceptor, as well as carbonates $\left(\mathrm{CO}_{3}^{2-}\right.$ and $\mathrm{HCO}_{3}^{-}$) as carbon source [14]. In the FSBR, the coral sand was the filler of flow-separated balls, of which the main component is metastable aragonite $\left(\mathrm{CaCO}_{3}\right)$ (Fig. S2c). The coral sand could slowly and persistently release $\mathrm{HCO}_{3}^{-}$to liquid phase [10], providing a carbon source for metabolism of Thiothrix. Meanwhile, domestic sewage contained some sulfide and organic sulfur compounds [23] that could offer an electron donor for metabolism of Thiothrix. Therefore, there were a large number of Thiothrix in the suspended sludge, loosely attached biofilm and tightly attached biofilm of the first region, of which their abundances were $10.55 \%, 3.20 \%$ and $2.72 \%$, respectively. Notably, 
Thiothrix was abundant in the suspended sludge of the first region. In addition, the abundances of Thiothrix in the three forms of microbial aggregate all decreased along the flow direction. In the FSBR, Proteobacteria participating in HD included Comamondesceae (such as unclassified_f_Comamonadace, Rhodoferax, Hydrogenophaga, Aquabacterium and Acidovorax), Rhodocyclaceae (such as Thauera, Zoogloea, Norank $f$ Hhodocyclaceae, Denitratisoma, Dechloromonas) and Hydrogenophilaceae (such as norank_f_Hydrogenophilaceae) in $\beta$-Proteobacteria, Xanthomonadaceae (such as Dokdonella) in $\gamma$-Proteobacteria, and Haliangiaceae (such as Haliangium) in $\delta$-Proteobacteria. In the first region, unclassified_f_Comamonadace, Acidovorax and Dokdonella were the major HD bacteria. The abundances of unclassified_f_Comamonadace in suspended sludge, loosely attached biofilm and tightly attached biofilm were $2.72 \%, 3.24 \%$ and $2.72 \%$, respectively. The abundances of Acidovorax in the above three forms of microbial aggregate were $3.11 \%$, 5.94\% and $5.02 \%$, respectively. The abundance of Dokdonella in the above three forms of microbial aggregate were $0.71 \%, 2.23 \%$ and $5.57 \%$, respectively. It has been reported that unclassified_f_Comamonadace [4, 19, 15], Aquabacterium [18], Acidovorax [4, 15], Thauera [24], norank_f_Rhodocyclaceae [1], Denitratisoma [18] and Dokdonella [16, 17] were aerobic denitrifying bacteria. In the first region, their total abundances in suspended sludge, loosely attached biofilm and tightly attached biofilm were $10.37 \%, 17.13 \%$ and $18.22 \%$, respectively. Furthermore, the abundances of Rhodoferax, Hydrogenophaga, Zoogloea, norank_f Hydrogenophilaceae and Dechloromonas in the three forms of microbial aggregate also decreased along the flow direction, which was similar to the variations of the abundances of the above seven aerobic denitrifying bacteria, suggesting that they all might be aerobic denitrifying bacteria. These results indicated that aerobic denitrification played a key role in denitrification.

The first region removing $49.50 \pm 9.29 \%$ of $\mathrm{TN}$ was the key area for TN removal. However, the amounts of autotrophic AOB and NOB all were far lower than those of sulfide-autotrophic denitrifying bacteria and aerobic denitrifying bacteria in the three forms of microbial aggregate of the first region. Furthermore, the abundances of $\mathrm{AOB}$ and NOB in the three forms of microbial aggregate all increased along the flow direction. It had been reported that most aerobic denitrifying bacteria had the function of heterotrophic nitrification [2]. Thereby, heterotrophic nitrificationaerobic denitrifying bacteria played an important role in SND [2, 9]. In previous studies, little attention has been paid to heterotrophic nitrification-aerobic denitrifying bacteria in Proteobacteria. Only Dokdonella was known as an heterotrophic nitrification-aerobic denitrification bacteria. In the study, Dokdonella was enriched in the tightly attached biofilm of the first region, of which the abundance was $5.57 \%$. Although autotrophic nitrifying bacteria had strong nitrification ability [21], heterotrophic nitrification-aerobic denitrifying bacteria were more suitable for high organic loading environmental conditions [2]. Thereby, the nitrification process in the first region should be the result of a combination of autotrophic nitrification and heterotrophic nitrification.

\section{Conclusions}

Coral sand had rough surface and porous structure, which was suitable as a biofilm carrier. The FSBR filled with abandoned coral sand had a good performance of SND, in which there was a strong positive correlation between the removal efficiencies of $\mathrm{NH}_{4}^{+} \mathrm{-N}$ and $\mathrm{TN}$. In the period of stable operation, the $\mathrm{TN}$ removal efficiency of the FSBR was $74.68 \pm 6.49 \%$, when the ratio of air to water was $25: 1$ and the DO concentrations in effluent were greater than $2 \mathrm{mg} / \mathrm{L}$. Meanwhile, there was a strong positive correlation between the DO concentration and the $\mathrm{pH}$ value in effluent, indicating that the SND in FSBR could effectively compensate for alkalinity consumption in the nitrification process. In addition, the tightly attached biofilm was an important microbial aggregate, of which the amount was $62.19-63.65 \%$ of the total biomass. The total biomass and removal efficiencies of pollutants in the three reaction regions all decreased along the flow direction. Thereby, the first region was the key area for $\mathrm{SND}$ reaction and $\mathrm{TN}$ removal. In the first region, the nitrification process was the result of the combination of autotrophic nitrification and heterotrophic nitrification. Meanwhile, aerobic denitrification played a key role in the process of denitrification. In the region, the most denitrifying bacteria belonged to Proteobacteria, in which unclassified_f_Comamonadace, Acidovorax and Dokdonella were the major aerobic denitrifying bacteria.

\section{Acknowledgements}

This work was supported by the National Natural Science Foundation of China [grant No. 21577174] and the Chongqing Basic Science and Advanced Technology Research [grant Nos. CSTC2015jcyjB0390, CSTC2014jcyjA20004, and CSTC2015jcyjA20012].

\section{Conflicts of Interest}

The authors declare no conflict of interest.

\section{References}

1. KIM E., SHIN S.G., MAH J., TONGCO J.V., HWANG $\mathrm{S}$. Use of food waste-recycling wastewater as alternative 
carbon source for denitrification process: A full-scale study. Bioresource Technology. 245, 1016, 2017.

2. WANG J., GONG B., HUANG W., WANG Y., ZHOU J. Bacterial community structure in simultaneous nitrification, denitrification and organic matter removal process treating saline mustard tuber wastewater as revealed by $16 \mathrm{~S}$ rRNA sequencing. Bioresource Technology. 228, 31, 2017.

3. ZHAO J., FENG L., YANG G., DAI J., MU J. Development of simultaneous nitrification-denitrification (SND) and organics removal in biofilm reactors with partially coupled a novel biodegradable carrier for nitrogen-rich water purification. Bioresource Technology. 243, 800, 2017.

4. RUAN Y.J., DENG Y.L., GUO X.S., TIMMONS M.B., LU H.F., HAN Z.Y., YE Z.Y., SHI M.M., ZHU S.M. Simultaneous ammonia and nitrate removal in an airlift reactor using poly (butylene succinate) as carbon source and biofilm carrier. Bioresource Technology. 216, 1004, 2016.

5. THIRD K.A., BURNETT N., CORD-RUWISCH R. Simultaneous nitrification and denitrification using stored substrate (PHB) as the electron donor in an SBR. Biotechnology \& Bioengineering. 83 (6), 706, 2003.

6. JIAWEI H., JUN L. Aerobic denitrification characteristics of a flow-separation reactor under oxygen-rich environment. Acta Scientiae Circumstantiae. 36 (2), 521, 2016.

7. HU J., LI J., BIAN W., WANG M. Denitrification characteristics in oxygen-enriched continuous anoxic/ aerobic biofilm system for municipal wastewater treatment. Ciesc Journal. 65 (10), 4071, 2014

8. PEREIRA A.D., LEAL C.D., DIAS M.F., ETCHEBEHERE C., CHERNICHARO C.A., DE ARAÚJO J.C. Effect of phenol on the nitrogen removal performance and microbial community structure and composition of an anammox reactor. Bioresource Technology. 166 (8), 103, 2014.

9. WEN Y., WEI C.H. Heterotrophic nitrification and aerobic denitrification bacterium isolated from anaerobic/anoxic/ oxic treatment system. African Journal of Biotechnology. 10 (36), 6985, 2011.

10. CHOU J., BEN-NISSAN B., CHOI A.H., WUHRER R., GREEN D. Conversion of coral sand to calcium phosphate for biomedical application. J. Aust. Ceram. Soc. 43 (1), 44, 2007.

11. CLESCERI L.S., GREENBERG A.E., EATON A.D. Standard methods for the examination of water and wastewater, $20^{\text {th }}$ ed. APHA, Washington D.C. 1999.

12. DELATOLLA R., BERK D., TUFENKJI N. Rapid and reliable quantification of biofilm weight and nitrogen content of biofilm attached to polystyrene beads. Water Research. 42 (12), 3082, 2008.

13. GAO D.W., WEN Z.D., LI B., LIANG H. Membrane fouling related to microbial community and extracellular polymeric substances at different temperatures. Bioresource Technology. 143 (1), 172, 2013.

14. HOWARTH R., UNZ R.F., SEVIOUR E.M., SEVIOUR R.J., BLACKALL L.L., PICKUP R.W. Phylogenetic relationships of filamentous sulfur bacteria (Thiothrix spp. and Eikelboom type $021 \mathrm{~N}$ bacteria) isolated from wastewater-treatment plants and description of Thiothrix Eikelboomii sp. nov. Thiothrix Unzii sp. nov. Thiothrix Fructosivorans sp. Int J Syst Bacteriol. 49 (4), 1817, 1999.
15. HUANG X., LI W., ZHANG D., QIN W. Ammonium removal by a novel oligotrophic Acinetobacter sp. Y16 capable of heterotrophic nitrification-aerobic denitrification at low temperature. Bioresource Technology. 146 (10), 44, 2013.

16. LI Y., ZHANG J., CHEN Q., YANG G., CAI S., HE J., ZHOU S., LI S.P. Dokdonella kunshanensis sp. nov., isolated from activated sludge, and emended description of the genus Dokdonella. International Journal of Systematic \& Evolutionary Microbiology. 63 (4), 1519, 2013.

17. XING W., LI D., LI J., HU Q., DENG S. Nitrate removal and microbial analysis by combined micro-electrolysis and autotrophic denitrification. Bioresource Technology. 211, 240, 2016

18. WANG H., HU C., LI X. Characterization of biofilm bacterial communities and cast iron corrosion in benchscale reactors with chloraminated drinking water. Engineering Failure Analysis. 57, 423, 2015.

19. TIAN H.L., ZHAO J.Y., ZHANG H.Y., CHI C.Q., LI B.A., WU X.L. Bacterial community shift along with the changes in operational conditions in a membrane-aerated biofilm reactor. Applied Microbiology \& Biotechnology. 99 (7), 3279, 2015.

20. Zuber H. Structure of light-harvesting antenna complexes of photosynthetic bacteria and red algae. Trends in Biochemical Sciences. 11 (10), 414, 1986.

21. CHEN Y., ZHAO Z., PENG Y., LI J., XIAO L., YANG L. Performance of a full-scale modified anaerobic/anoxic/ oxic process: High-throughput sequence analysis of its microbial structures and their community functions. Bioresource Technology. 220, 225, 2016.

22. KARKMAN A., MATTILA K., TAMMINEN M., VIRTA M. Cold temperature decreases bacterial species richness in nitrogen-removing bioreactors treating inorganic mine waters. Biotechnology \& Bioengineering. 108 (12), 2876, 2011.

23. ARAÚJO A.L.C., OLIVEIRA R.D., MARA D., SILVA S.A. Sulphur and phosphorus transformations in wastewater storage and treatment reservoirs in northeast brazil. Water Science \& Technology. 42 (10), 203, 2000.

24. ZHAO Y., HUANG J., ZHAO H., YANG H. Microbial community and $\mathrm{N}$ removal of aerobic granular sludge at high COD and $\mathrm{N}$ loading rates. Bioresource Technology. 143, 439, 2013.

25. VANDERMAESEN J., LIEVENS B., SPRINGAEL D. Isolation and identification of culturable bacteria, capable of heterotrophic growth, from rapid sand filters of drinking water treatment plants. Research in Microbiology. 168 (6), 594, 2017.

26. CHAKRAVARTHY S.S., PANDE S., KAPOOR A., NERURKAR A.S. Comparison of denitrification between Paracoccus sp. and Diaphorobacter sp. Applied Biochemistry \& Biotechnology. 165 (1), 260, 2011.

27. LIU W., YANG D., CHEN W., GU X. High-throughput sequencing-based microbial characterization of size fractionated biomass in an anoxic anammox reactor for low-strength wastewater at low temperatures. Bioresource Technology. 231, 45, 2017.

28. WANG Z., HUANG F., MEI X., WANG Q., SONG H., ZHU C., WU Z. Long-term operation of an mbr in the presence of zinc oxide nanoparticles reveals no significant adverse effects on its performance. Journal of Membrane Science. 471, 258, 2014. 